\title{
ERISA Preemption and Indirect Regulation of Employee Welfare Plans Through State Insurance Laws
}

Leslie Levin

University of Connecticut School of Law

Follow this and additional works at: https://opencommons.uconn.edu/law_papers

Part of the Insurance Law Commons, and the Labor and Employment Law Commons

\section{Recommended Citation}

Levin, Leslie, "ERISA Preemption and Indirect Regulation of Employee Welfare Plans Through State Insurance Laws" (1978). Faculty Articles and Papers. 425.

https://opencommons.uconn.edu/law_papers/425 


\section{ERISA PREEMPTION AND INDIRECT REGULATION OF EMPLOYEE WELFARE PLANS THROUGH STATE INSURANCE LAWS}

\section{INTRODUCTION}

The Employee Retirement Income Security Act of 1974 (ERISA), 1 enacted to correct widespread abuses ${ }^{2}$ in the area of employee benefit plans, ${ }^{8}$ imposes federal minimum standards for plan reporting and disclosure, vest$\mathrm{mg}$, funding, and fiduciary responsibilities. ${ }^{4}$ To ensure national uniformity, ${ }^{6}$ section 514 preempts state laws that "relate to" employee benefit plans." Since ERISA affects many areas traditionally governed by state law, the extent to which states may continue to regulate certain activities whenever such regulation "relate[s] to" employee benefit plans has been the subject of much litigation. ${ }^{8}$

1. Pub. L. No. 93-406, 88 Stat. 829 (1974) (codified at 29 U.S.C. $\$ \S 1001-1381$ (1976)) [hereinafter cited as ERISA $\$$-].

2. After twelve years of investigation into various abuses of employee pension and welfare plans that had deprived many workers of their earned benefits, see 120 CoNo. Rrc. 29,934 (1974), Congress enacted ERISA to replace the Welfare and Pensions Plans Disclosure Act, Pub. L. No. 85-836, 72 Stat. 997 (1958), which had proven ineffective due to weak disclosure requirements and an even weaker enforcement mechanism. H.R. RRP. No. 93-533, 93d Cong., $2 \mathrm{~d}$ Sess., reprinted in [1974] U.S. CODE CONG. \& AD. NEws 4639, 4642; S. RRP. No. 93-127, 92d Cong., 2d Sess., reprinted in [1974] U.S. Code Cono. \& AD. NEws 4838, 4841; S. Rap. No. 1150, 92d Cong., $2 \mathrm{~d}$ Sess. 5 (1972). For a discussion of the evolution of the federal legislation governing employee benefit plans, see Chadwick \& Foster, Federal Regulation of Retirement Plans: The Quest for Parity, 28 VAND. L. Rev. 641, 642-68 (1975); Snyder, Employee Retirement Income Security Act of 1974, 11 WAKE FOREST L. REv. 219, 226-46 (1975).

3. The term "enuployee benefit plan," ERISA $\$ 3(3), 29$ U.S.C. $\$ 1002(3)$, includes any fund or program nuaintained by an employer, an enployee organization, or both, that provides medical, disability, or certain other benefits through the purchase of insurance or otherwise (an "employee welfare benefit plan," ERISA § 3(1), 29 U.S.C. \$1002(1) (1976)), or that provides retirenuent income to employees (an "employee pension benefit plan," ERISA \& 3(2), 29 U.S.C. $\$ 1002(2)(1976)$ ).

4. Title I of ERISA, $\$ \S 1-514,29$ U.S.C. $\$ \$ 1001-1144$ (1976), is divided into five parts. Part one applies reporting and disclosure requirements to both pension and welfare plans. Part two, creating minimum vesting standards, and part three, reltating to funding requirements, apply only to employee pension benefit plans. Part four establishes a "prudent man" fiduciary standard for the administrators of all employee benefit plans, and part five provides for civil and criminal penalties for violation of the statute and grants various administrative powers to the Departments of Labor and the Treasury.

Title II of ERISA, $\S \S 1001-2008$, mcludes amendments to the Internal Revenue Code that relate to employee pension plans. E.g., I.R.C. $\$ \S 410-415$. Title III, ERISA $\$ \$ 3001-3043,29$ U.S.C. $\$ \S 1201-1242$ (1976), defines the jurisdiction of the Departments of Labor and the Treasury, and title IV, $\$ \$ 4001-82,29$ U.S.C. $\$ \$ 1301-81$ (1976), establishes the Pension Benefit Guaranty Corporation to protect pension plan beneficiaries in the event that the plan's funding is inadequate.

For a more detailed description of title I, see Brummond, Federal Preemption of State Insurance Regulation Under ERISA, 62 IowA L. Rev. 57, 61-63 (1976). For a discussion of the scope of the other titles, see Chadwick \& Foster, supra note 2, at 671-81; Note, The Employee Retirement Income Security Act of 1974: Policies and Problems, 26 SYRAcUSB L. Rev. $539,549-54$ (1975).

5. See 120 Cong. Rec. 29,933 (1974) (remarks of Sen. Williams); 120 Cono. RBc. 29,197 (1974) (remarks of Rep. Dent).

6. ERISA § 514(a), 29 U.S.C. \$1144(a) (1976).

7. See note 78 and accompanying text infra.

8. See, e.g., Wayne Chem., Inc. v. Columbus Agency Serv. Corp., 567 F.2d 692 (7th Cir. 1977) (state regulation of insurers); Wadsworth v. Whaland, 562 F.2d 70 (1st Cir. 1977), 
The scope of ERISA's preemption of state law is delineated in three subsections of the statute. Section 514(a) provides that all state laws ${ }^{9}$ are superseded by titles I and IV of ERISA ${ }^{10}$ insofar as they "relate to" einployee benefit plans. ${ }^{11}$ This sweeping language is modified by the saving clause of section $514(\mathrm{~b})(2)(\mathrm{A})$, which exempts state laws regulating insurance, banking, and securities from the scope of section 514(a).12 The saving clause is in turn limited by section 514(b) (2) (B), which provides that no employee benefit plan shall be "deemed" by a state to be an insurance company, bank, investment company, or engaged in those businesses for the purpose of any state laws regulating those areas. ${ }^{13}$

The statutory scheme thus excludes from preemption most state regulation of the insurance industry. ${ }^{14}$ However, state laws directly regulating insurance may have an indirect, ${ }^{15}$ yet profound impact on the terms and costs of employee benefit plans. ${ }^{16}$ For example, a state law may

cert. denied, 435 U.S. 980 (1978) (insurance companies); Standard Oil v. Agsalud, 442 F. Supp. 695 (N.D. Cal. 1977) (health care plans); In re C.D. Moyer Co. Trust Fund, 441 F. Supp. 1128 (E.D. Pa. 1977) (trusts); Old Stone Bank v. Michaelson, 439 F. Supp. 252 (D.R.I. 1977) (banks); Bell v. Employee Security Benefit Ass'n, 437 F. Supp. 382 (D. Kan. 1977) (insurers); Hewlett-Packard Co. v. Barnes, 425 F. Supp. 1294 (N.D. Cal. 1977), affd per curiam, 571 F.2d 502 (9th Cir.), cert. denied, 99 S. Ct. 108 (1978) (state regulation of health care plans); Insurers' Action Council, Inc. v. Heaton, 423 F. Supp. 921 (D. Minn. 1976) (insurance companies); Azzaro v. Hamett, 414 F. Supp. 473 (S.D.N.Y. 1976), affd, 553 F.2d 93 (2d Cir.), cert. denied, 434 U.S. 824 (1977) (pension funds).

9. ERISA \& 514 (c)(1), 29 U.S.C. \$1144(c)(1) (1976), defines "state law" as "all laws, decisions, rules, regulations, or other State action having the effect of law, of any State." Under id. $\$ 514$ (c) (2), 29 U.S.C. $\$ 1144$ (c)(2) (1976), "state" includes: "a State, any political subdivisions thereof, or any agency or instrumentality of either, which purports to regulate, directly or indirectly, the terms and conditions of employee benefit plans covered by this title.

10. See note 4 supra.

11. ERISA $\$ 514$ (a), 29 U.S.C. $\$ 1144$ (a) (1976), provides in pertinent part:

Except as provided in subsection (b) of this section, the provisions of this title and title IV shall supersede any and all State laws insofar as they may now or hereafter relate to any employee benefit plan described in section $4(a)$ and not exempt under section $4(\mathrm{~b})$.

12. Id. $\$ 514$ (b) (2)(A), 29 U.S.C. $\$ 1144(\mathrm{~b})(2)(\mathrm{A})$ (1976), provides:

Except as provided in subparagraph (B), nothing in this subchapter shall be construed to exempt or relieve any person from any law of any State which regulates insurance, banking, or securities.

13. Id. $\$ 514$ (b)(2) (B), $\$ 1144$ (b) (2) (B) (1976), provides:

Neither an employee benefit plan described in section $4(a)$ of this title . . . nor any trust established under such a plan, shall be deemed to be an insurance company or other insurer, bank, trust company, or investment company or to be engaged in the business of insurance or banking for the purpose of any law of any State purporting to regulate insurance companies, insurance contracts, banks, trust companies, or investment companies.

14. See note 12 supra. The special status of state insurance laws is also evident in the McCarran-Ferguson Act, 15 U.S.C. $\$ 1012$ (b) (1976), which provides:

No Act of Congress shall be construed to invalidate, impair, or supersede any law euacted by any State for the purpose of regulating the business of insurance ... unless such Act specifically relates to the business of insurance ....

This language is implicitly reaffirmed by $\$ 514$ (d) of ERISA, 29 U.S.C. $\$ 1144$ (d) (1976), which provides that ERISA does not alter existing federal law. See note 26 infra.

15. "Indirect regulation," as used in this Comment, refers to those laws, not specifically directed to employee benefit plans, which have the unavoidable effect of altering the conduct or terms of the plan.

16. Employee welfare plans may secure insurance in three different ways. First, group insurance policies may be purchased froin private insurance companies. A second method is self-insurance, in which the plan assumes the risk of loss by setting aside funds to pay for 
require that insurance policies issued to employee welfare plans ${ }^{17}$ provide coverage for specified disabilities, and thus indirectly impose additional burdens on the plans theinselves.

This Comment considers whether the preemption provisions of ERISA cover state insurance laws that indirectly regulate employee welfare plans. ${ }^{18}$ The Comment focuses on the approach to the problem taken by the United States Court of Appeals for the First Circuit in Wadsworth v. Whaland, ${ }^{10}$ and concludes that, absent statutory reform, the best solution would be to construe ERISA as preempting state insurance laws only in those areas specifically regulated by the Act.

\section{Preemption of State Laws under Section 514}

\section{A. The First Circuit's Approach in Wadsworth v. Whaland}

The Whaland case illustrates the principal issues raised by state insurance laws that indirectly regulate employee benefit plans. New Hampshire enacted a statute mandating that group insurance policies, including those issued to employee welfare plans, include coverage for emotional disorders. ${ }^{20}$ Administrators of various employee welfare plans challenged the statute, alleging that its indirect regulation of the plans violated the preemption provisions of ERISA. The district court found that ERISA's legislative history failed to address the issue of preemption of substantive insurance statutes. The court, however, essentially viewed ERISA as regulating the reporting and funding requirements for employee welfare plans and thus concluded that section 514(a) preeinpted only those areas specifically regulated by the Act.21

specified expenses incurred by plan beneficiaries. Finally, a plan may contract with a health maintenance organization (HMO) or other professional group to provide direct care for plan beneficiaries. For a thorough discussion of the theory of imsurance as it relates to employee welfare benefit plans, see Brummond, supra note 4, at 67-79.

The question, crucial to ERISA preemption analysis, of who is the insurer in these arrangements depends upon who has assuuned the risk. See generally ESSAYS IN THE THEORY Op RISI and Insurance 149 (J.D. Hammond ed. 1968); F. Mzhr \& E, Cammack, Prnnciples of INSURANCB 17 (5th ed. 1972). A plan that engages in self-insurance is itself the insurer because it bears the risk of loss. When a plan obtains coverage from an insurance company or FMO, those entities bear the risk, and are therefore the insurers.

17. The term "employee welfare plan" will be used throughout this Comment to denote employee welfare benefit plans as defined at ElRISA §3(1), 29 U.S.C. §1002(1) (1976). See note 3 supra.

18. Although this Comment focuses on the ways in which state insurance law may affect employee vielfare plans, much of the analysis is equally applicable to the preemption of state banking and securities laws under ERISA.

19. 562 F.2d 70 (1st Cir. 1977), cert. denied, 434 U.S. 1044 (1978).

20. N.H. REv. STAT. ANN. $\$ \$ 415: 18-a, 419: 5-a, 420: 5$-a (Supp. 1977). In particular, the

New Hampshire statute considered in Whaland required:

Each insurer that issues or renews any policy of group or blanket accident or health insurance providing benefits for medical or hospital expenses, shall provide to each group, or to the portion of each group comprised of certificate holders of such insurance who are residents of this state and whose principal place of employment is in this state, coverage for expenses arising from the treatment of mental illnesses and emotional disorders .....

21. Dawson v. Whaland, No. 76-266 (D.N.H. Feb. 11, 1977) (available on Lexis), aff'd sub nom. Wadsworth v. Whaland, 562 F.2d 70 (1st Cir. 1977). Although the court nover 
Since the New Hampshire statute did not regulate substantive areas governed by ERISA, preemption was denied.

On appeal, the First Circuit affirmed the holding below, but advanced a different rationale. The court characterized the New Hampshire statute as an insurance law regulating insurers, and found that the employee welfare plans were insureds, and therefore not insurers directly regulated by the state law. ${ }^{22}$ The court concluded that section $514(b)(2)(B)$ - the "deemer" provision of ERISA ${ }^{23}$ — did not prohibit states from indirectly affecting employee welfare plans by regulating the contents of group insurance policies. ${ }^{24}$ Relying upon the "national policy of state primacy in the regulation of insurance". reflected in ERISA's saving clause for state insurance laws ${ }^{25}$ and on section 514(d) of the Act, which preserves federal law $^{26}$ and implicitly reaffirms the McCarran-Ferguson Act, ${ }^{27}$ the court held that the state statute was not preempted by ERISA. ${ }^{28}$

explicitly stated that preemption was limited to those areas regulated by ERISA, it strongly implied this conclusion. Id. n.2. To bolster its loolding that the state statute was not preempted by $\$ 514$, the court reasoued that because ERISA was not primarily concerned with the regulation of insurance, the McCarran-Ferguson Act prevented preemption. See note 14 supra.

22. 562 F.2d at 76. The plans, as purchasers of insurance policies, had shifted the risk of loss to private insurance companies, who were the "insurers" in this case. Since the plan lad paid a set premium in exchange for the imsurance company's agreement to pay an undetermined number of claims, the insurance company bore the risk of loss. See note 16 supra.

23. See note 13 supra.

24. 562 F.2d at 78. This conclusion implicitly answers in the negative the question, raised under traditional preemption analysis, of whether the state law "conflicts or interferes" with the federal statute. To make this determination, courts typically analyze whether the state law obstructs the operation of the federal law. See Note, The Preemption Doctrine: Shifting Perspectives on Federalism and the Burger Court, 75 CoLUM. L. REv. 623, 626 (1975). The question of whether Congress intended to occupy the entire field that it was regulating, to the exclusion of any state laws on the subject, represents the second straud of traditional preemption analysis. To answer this question, a court considers whether the statute expressly bars state regulation of a subject; whether the scheme of federal regulation is so pervasive that it leaves no room for state regulation; whether the statute touclies a field in which the federal interest is so great that state law cannot be permitted to operate; and whether the federal law governs a field in which the need for national uniformity is so great that divergent state laws cannot be tolerated. See Hirsch, Toward a New View of Federal Preemption, 1972 ILL. L.F. $515,529-31$.

It is unclear why neither the Whaland court nor most other courts, see note 8 supra, have employed judicially developed federal standards of preemption when analyzing ERISA. This failure may reflect a belief that these standards should not be invoked where Congress has explicitly expressed its intention to preempt through a statute. See Jones v. Rath Packing Co., 430 U.S. 519, 525-26 (1977) (congressional intent to preempt state laws must be found where Congress's command is explicitly stated in the statute's language or implicitly contained in its structure and purpose).

25. 562 F.2d at 78; see text accompanying note 32 infra. The court found that Congress was aware of the relation of employee benefit plans to insurance, as evidenced by its definition of "employee welfare benefit plan," and nonetheless exempted state insurance laws from preemption. Id.

26. ERISA $\$ 514($ d), 29 U.S.C. $\$ 1144$ (d) (1976), provides: "Nothing in this subchapter shall be construed to alter, amend, modify, invalidate, impair or supersede any law of the United States . . . or any rule or regulation issued under any such law."

27. See note 14 supra.

28. The court of appeals also rejected a commerce clause challenge to the New Hampshire statute, finding that Congress had intended to leave the regulation of insurance to the states. 562 F.2d at 79. Noting that Congress lias the power to decline to protect interstate commerce, the court lield that Congress had intended that the states regulate insurance, as evidenced by ERISA and the McCarran-Ferguson Act. Id. 


\section{B. Statutory Interpretation}

Textual analysis of the preemption section of ERISA supports the First Circuit's finding that the Act permits indirect state regulation of employee benefit plans. The structure of section 514 suggests great deference on the part of Congress to state insurance regulation: the sweeping preemption of state law is followed by a broad exception for state imsurance laws, with one limited qualification. The statute also reaffirms all federal laws, including the McCarran-Ferguson Act, which upholds the primacy of the states' role in regulating insurance. ${ }^{29}$ In addition, Congress provided that the provisions of titles I and IV supersede state law, ${ }^{30}$ indicating that it intended to preempt only those state laws that conflict with the limited areas regulated by these two titles. ${ }^{31}$

Further support for the First Circuit's holding in Whaland nay be gleaned from a careful reading of section 514, which indicates that state insurance laws are preempted only when the employee welfare plan is "deemed" to be an insurer under state law. Section 514(b)(2)(B), the single exception to the saving clause, prevents regulation of employee benefit plans under state insurance laws that "deem" such plans to be engaged in the business of insurance. The provision, however, does not mention the status of state insurance laws that do not "deem" employee welfare plans to be insurers but nonetheless regulate other insurers who provide coverage for the plans. Presumably, such insurance laws could continue in effect under the protection of the saving clause..$^{32}$ Indeed, section 514 (b)(2)(B) seeins aimed solely at preventing states from regulating employee welfare plans by calling them insurers and taking advantage of the exemption froin preemption under section 514(a). The language of the deemer clause deals only with this particular type of subterfuge, and it is difficult to read in a prohibition against all indirect regulation of employee benefit plans in light of its apparently limited purpose.

Finally, as the court of appeals noted in Whaland, to interpret section 514 to forbid indirect regulation of employee welfare plans by state insurance laws would emasculate the saving clause. ${ }^{33}$ Insurance laws that do not "relate to" employee welfare plans are clearly not affected by the preemption language of section 514(a) and therefore do not need the protection of the saving clause. Correspondingly, direct regulation of employee welfare plans

29. See note 14 supra.

30. See note 11 supra.

31. Had Congress intended otherwise, it might easily have provided: "the provisions of this Act shall supersede any and all state laws insofar as they relate to employee benefit plans." See Brummond, supra note 4, at 125 (suggesting language that preempts state law only insofar as such laws conflict with the sections of ERISA). But see note 43 and accompanying text infra. Although the district court found that preemption was limited to those areas that Congress regulated, Dawson v. Whaland, No. 76-266 (D.N.H. Feb. 11, 1977) (available on Lexis), the court of appeals did not address this argument, instead preferring a textual argument, Wadsworth v. Whaland, 562 F.2d 70, 75-78 (1st Cir. 1977). See note 21 and accompanying text supra.

32. See note 12 supra.

33. $562 \mathrm{~F} .2 \mathrm{~d}$ at 78 . 
by state insurance laws is forbidden by section 514 (b)(2)(B). Thus, for the saving clause to have meaning, section 514 must permit state insurance laws indirectly to affect einployee welfare plans. Otherwise, no insurance laws affected by ERISA are preserved under section 514(b) (2)(A).

Textual arguments against the Whaland court's conclusions appear, upon close analysis, to have little merit. Since the definition of "state" includes a political subdivision that purports to regulate, directly or indirectly, enployee benefit plans, it could be argued that Congress intended to preempt indirect regulation of such plans. ${ }^{34}$ The word "state" appears in both the preemption section and in the exemption to it, however, indicating that while indirect regulation by inost "state" laws is preempted, indirect regulation by "state" insurance laws is not. ${ }^{35}$ Similarly, the inclusion, in ERISA's definition of "state," of entities that regulate the terms and conditions of employee benefit plans, ${ }^{36}$ might be read to support preemption of state-imposed insurance benefits. Specifically, it could be argued that preemption of statemandated benefits was required under section 514(a) simce such requirements arguably constitute "conditions" of an employee benefit plan. ${ }^{37}$ Nonetheless, the response to this argument resembles the earlier one-even if "terms and conditions" should be construed broadly, ${ }^{38}$ their sweeping preemption under section 514(a) results in an equally broad exemption for the terms and conditions of state insurance laws under the saving clause.

A somewhat more plausible argument against the Whaland court's conclusions may be made from the text of the McCarran-Ferguson Act. While both the district court and the court of appeals relied upon the implicit reaffirmation of the McCarran-Ferguson Act in section 514(d), ${ }^{39}$ that Act could also support a finding of sweeping preemption. The McCarran-Ferguson Act does not permit federal law to supersede any state insurance law unless the federal act "specifically relates to" the busimess of insurance. ${ }^{40}$ Proponents of the view that ERISA also preempts indirect regulation of einployee welfare plans could argue that ERISA "specifically relates to" the busmess of insurance because it preempts insurance law. The First Circuit apparently bekieved that ERISA does not specifically relate to the busimess of insurance, however, and that the McCarran-Ferguson Act therefore prohibits the preemption of state insurance laws by ERISA.41

34. See note 9 supra. The Whaland court rejected this argument made by the plaintiffs, 562 F.2d at 78, using somewhat different reasoning. See notes 49-51 infra.

35. See notes 11-12 supra.

36. See note 9 supra.

37. This arguinent was made in the ERISA Industry Committee's (ERIC) brief in Whaland, Brief Amicus Curiae of the ERISA Industry Committee at 10, Wadsworth $v$. Whaland, 562 F.2d 70 (1st Cir. 1977), but was not considered by the court.

38. The words "terms and conditions" are quite ambiguous, and while they may be read broadly to include types of medical coverage afforded plan beneficiaries, they may simply include the terms and conditions covered by ERISA.

39. See note 21; text accompanying note 27 supra.

40. See note 14 supra.

41. 562 F.2d at $78 \&$ n.41. The court never articulated its basis for finding that ERISA did not meet the terms of the McCarran-Ferguson Act. The district court, on the other hand, had concluded that the McCarran-Ferguson Act precluded preemption of state insurance laws 


\section{Legislative History}

The legislative history of section 514 does little to clarify the intent of Congress with regard to indirect regulation of employee welfare plans through state insurance laws. Instead, it indicates that Congress neither understood nor considered the broader implications of preemption. ${ }^{42}$ Earlier versions of the House and Senate preemption sections provided that federal law would supersede state law only in those areas specifically regulated by ERISA.43 The conference committee deleted the language limiting preemption to areas governed by ERISA-thereby significantly expanding the scope of preemption ${ }^{44}$ - but gave no meaningful explanation for the change. ${ }^{45}$

The debates preceding the enactment of the conference committee's version of the bill indicate that preenption of all state laws relating to employee benefit plans was intended-whether or not ERISA also regulated the activity. 46 These debates, however, fail to clarify whether Congress intended to preempt indirect as well as direct state regulation of these plans. For example, Representative John Dent simply noted "what is to many the crown-

because ERISA "is not primarily concerned with the regulation of insurance." Dawson v. Whaland, No. 76-266 (D.N.H. Feb. 11, 1977) (available on Lexis) (emphasis supplied). In reaching this conclusion, the court noted that ERISA deals almost entirely with reporting provisions and various aspects of retirement funds. This "primarily concerned with" test is obviously more stringent than the "specifically relates to" language of the McCarran-Ferguson Act, and would seem to misdirect the analysis by considering the extent of an act's concern with insurance, rather than the directness of its regulation of the area.

42. The language of the final version of $\S 514$ was a radical departure from earlier formulations, see text accompanying note 44 infra, and was apparently adopted without further hearings on preemption, although there had been extensive hearings before the earlier language was drafted. See Hewlett-Packard Co. v. Barnes, 425 F. Supp. 1294, 1298 n.12 (N.D. Cal. 1977), affd per curiam, 571 F.2d 502 (9th Cir.), cert. denied, 99 S. Ct. 108 (1978). Because this change was disclosed two weeks before the final vote on ERISA, the legislators had little time to evaluate its implications for the rest of the lengthy and complex bill. See 30 CoNo. Q. Almanac 252 (1974). In addition, it is unlikely that Congress devoted its complete attention to the conference reports because they were released within days of the resignation of Presideat Richard Nixon.

43. See, e.g., S. 4, 93d Cong., 1st Sess. $\S 609$ (a), 119 Cong. Rec. 141-42 (1973) (emphasis added):

It is hereby declared to be the express intent of Congress that . . . the provisions of this Act or the Welfare and Pension Plans Disclosure Act shall supersede any and all laws of the States and political subdivisions thereof insofar as they may now or hereafter relate to the subject matters regulated by this Act or the Welfare and Pension Plans Disclosure Act .... .

See also H.R. 2, 93d Cong., 1st Sess. §514(d) (1973) (emphasis added):

It is hereby declared to be the express intent of Congress that the provisions of Tilles

II and III shall supersede any and all laws of the States and of political subdivisions insofar as they may now or hereafter relate to the vesting of participant's benefits in employee benefit plans, the funding requirements for employee benefit plans or the adequacy of financing employee benefit plans.

44. Compare note 11 supra with note 43 supra.

45. See H.R. RBP. No. 1280, 93d Cong., $2 d$ Sess. 383 (1974), reprinted in [1974] U.S. CODB CONG. \& AD. NEWS 5038, 5162.

46. This conclusion is reinforced not only by the change made in conference committee, see notes $43-44$ and accompanying text supra, but also by the committee's apparent rejection of the administration's recommendations regarding preemption. These recommendations included limiting federal preemption to specific areas such as participation, funding, vesting, etc. See Administration Recommendations to the House and Senate Conferees of H.R. 2 to Provide for Pension Reform, reprinted in 3 SUBCOMM. ON LABOR OF THB SBN. COMM. ON LABOR \& Public Welfare, 94Th Cong., 2D Sess., Legislative History of the EMPLOYeE Retimement INCOMB SECURTYY ACT OF 1974, at 5145 (1976). 
ing achievement of this legislation [is] the reservation to Federal authority [of] the sole power to regulate the field of employee benefit plans." 47 Senator Jacob Javits, one of the bill's sponsors, indicated that "[c]omprehensive and pervasive federal interest and the interests of uniformity with respect to interstate plans required-but for certain exceptions-the displacement of State action in the field of private employee benefit programs." 48

The court of appeals in Whaland implicitly acknowledged that the clear congressional intent to preempt all types of state laws relating to employee benefit plans was analytically distinct from the unanswered question of whether indirect state regulation of sucli plans would be permitted. Relying on the congressional debates, the court agreed that Congress demonstrated a broad preemptive intent, but found this intent to extend only to section 514(a). ${ }^{40}$ Because of this broad intent, state laws falling under section 514(a) were preempted even if they only tangentially related to employee benefit plans. Insurance laws, however, were exempted from this section by section $514(\mathrm{~b})(2)(\mathrm{A})$, and the court reasoned that any conflict between the sections must be resolved by the deemer clause. ${ }^{50}$ The deemer clause, it concluded, did not prohibit such indirect regulation of employee benefit plans. ${ }^{51}$

\section{Implications of Preemption}

\section{A. Impact of Wadsworth $\mathrm{v}$. Whaland}

The First Circuit's interpretation of section 514 in Whaland, permitting indirect regulation of employee welfare plans through the operation of state insurance laws, has far-reaching implications for the effectiveness of ERISA. By regulating insurance companies and their agents, a state can exert substantial control over many aspects of employee welfare plans. ${ }^{52}$ States may

47. 120 CoNG. REc. 29,197 (1974). Representative Dent, Chairman of the Subcommittee on Labor of the House Committee on Education and Labor, further noted that the conferees applied the principle of preemption in its "broadest sense to foreclose any non-Federal regulation of employee benefit plans." Id.

48. Id. at 29,942 .

49. 562 F.2d at 77. This conclusion is buttressed by the fact that the major change in \$514 related to the language that vas to become part of $\$ 514(a)$. See notes 11 \& 43 supra. In addition, a review of the congressional debates relating to broad preemption reveals that the congressmen could only have been referring to $\$ 514(\mathrm{a})$, because they never explicitly discussed the very obvious restrictions on preemption found in the rest of \$514. See 120 CoNG. REC. 29,942 (remarks of Sen. Javits); id. at 29,933 (remarks of Sen. Williams); id. at 29,197 (remarks of Rep. Dent).

50. 562 F.2d at 77 .

51. Congress never directly addressed this problem in its debates; the court thus relied on the face of the deemer provision and not on its legislative history. Id. at 78. The court apparently found the exemption for state insurance laws to be complete except in one situation-when the state "deemed" a plan to be engaged in the business of insurance and attempted to regulate it directly. Because no other exception to the exemption was made, the court concluded that indirect means of regulation were not precluded. Id. at 77-78.

52. Cf. Old Stone Bank จ. Michaelson, 439 F. Supp. 252 (D.R.I. 1977) (state can insist on approvimg benefit plan based on its right to supervise bank activities). Conceivably, under the Whaland analysis, the state could dictate the types of insureds with whom the insurance companies can do business and in that way impose certain requirements on the employee 
classify a certain law as an "insurance law," thereby determining whether or not a state law is preempted by ERISA and creating an additional means of affecting employee welfare plans. ${ }^{53}$ Furthermore, because it is not always clear whether an employee benefit plan is "deemed" an insurer, or whether it is simply being imdirectly affected by state law, the decision of the court of appeals invites the continuous hitigation that ERISA's sponsors feared. ${ }^{.4}$

The Whaland approach also undermines Congress's attempt to ensure uniform standards anong employee benefit plans. ${ }^{65}$ If indirect regulation of employee welfare plans is allowed, fifty sets of requirements may be imposed on the national enployer who attempts to offer health benefits to his employees. $^{56}$ This additional state regulation also contravenes the congressional desire to contain the costs of employee benefit plans so that employers will not be discouraged from instituting such plans. ${ }^{57}$ State-imposed requirements may increase costs directly-for example, by expanding the scope of benefits-and indirectly by adding to the administrative costs of coinplying with state insurance laws.58

Moreover, the court's decision will encourage employers and plan trustees to form self-imsured plans in order to qualify as insurers and thus avoid all state regulation. ${ }^{59}$ The Whaland court noted that the plans before it were insureds-not self-insurers-and indicated that if the New Hampshire statute had attempted to regulate employee welfare plans as insurers, it would

welfare plans. For example, the state may require that insurance companies sell policies only to insureds who have filed certain information with the state or who comply with certain fiduciary standards.

53. See 160 PENS. REP. (BNA) A-18 (Oct. 24, 1977) (testimony of Willie R. Barnes, California Commissioner of Corporations before Oversight Subcomm. of Sen. Comm. on Human Resources). But see Hewlett-Packard v. Barnes, 425 F. Supp. 1294, 1300 (N.D. Cal. 1977), aff'd per curiam, 571 F.2d 502 (9th Cir.), cert. denied, 99 S. Ct. 108 (1978) ("The fact that the state considers employee benefit plans to be a unique variety of insurance . . . makes no difference under ERISA."”).

54. See note 48 and accompanying text supra. For example, this problem might arise if a state imposed certain requirements on all trustees placing more than $\$ 1,000,000$ in trust, and the statute were placed within the state insurance code. The question would be whether tho law is improperly "deeming" the trust fund (which may be used to pay msurance premiums for employee welfare plans) to be an insurer, or whether it is simply indirectly regulating employee welfare plans by placing requirements on the plan administrators.

55. See note 5 and accompanying text supra.

56. See 189 PENS REP. (BNA) A-24 (May 22, 1978) (remarks of Deputy Associato Solicitor of the Department of Labor noting that if plan rehes on insurance companies to provide benefits, uniform national benefits will be impossible). Appellants in Whaland claimed that the New Hampshire law was an unconstitutional burden on interstate commerce becauso plan administrators were required to be fair and equal in the administration of the plan funds, and chapter 57 might conflict with jurisdictions having different insurance requirements. The court summarily rejected this argument.

57. See, e.g., S. ReP. No. 383, 93d Cong., 2d Sess. 18 (1974), reprinted in [1974] U.S. CODB CONG. \& AD. NEWS 4890, 4904: "[S]ince these plans are voluntary on the part of the employer and both the institution of new pension plans and increases in benefits depend upon employer willingness to participate ... it is necessary to take into account additional costs from the standpoint of the employer."

58. See Brief Amicus Curiae of the ERISA Regulations Industry Committee [ERIC] at 30-31, Wadsworth v. Whaland, 562 F.2d 70 (1st Cir. 1977) (estimating that the cost impact of state law on employee plans is at least five percent for administration expenses alone).

59. See note 16 supra. See also Brummond, supra noto 4 , at 100. 
clearly be preempted by section 514(b)(2)(B). ${ }^{80}$ Thus, New Hampshire now requires plans obtaining insurance policies from private companies to purchase mental health coverage, while self-insured plans are not-and under ERISA cannot be-lield to such an obligation. It seens unlikely that Congress intended that soine plans be indirectly subject to state laws, while other plans are exempt purely on the basis of the form of risk allocation that they choose $^{\text {B1 }}$ - but this is precisely the result which the Whaland analysis yields.

\section{B. Alternatives to the First Circuit Approach}

In ERISA, Congress established a Pension Task Force to deal with the probleins created by preeinption. ${ }^{62}$ Statutory changes responsive to the questions raised by section 514 are now widely expected. ${ }^{63}$ Analysis of the problems raised by the court of appeals' approach in Whaland indicates that there are soine alternatives available that involve little or no change in the statutory scheine. These solutions seein to simplify the problems of preemption, while proinoting the congressional goals of reasonable cost, uniformity, and avoidance of litigation.

1. Statutory Reform. The simplest response to the problems raised by section 514 would be to amend that section so that preemption applies to einployee pension plans but not to einployee welfare plans. ${ }^{64}$ Such a result would allow federal dominance of pension regulation to continue intact-a desirable result since there has been little trouble with section 514 in the pension context. ${ }^{65}$ Unfortunately, preempting only state regulation of employee pension plans would not solve the problems that precipitated enactment of ERISA. Concurrent state and federal regulation of employee welfare plans would remain, and many of the same problems found in the Whaland approach, including extra costs and lack of national uniformity, ${ }^{86}$ would persist.

60. 562 F.2d at 76. Since $\S 514(\mathrm{~b})(2)(B)$ provides that any state insurance law that "deems" a plan to be an insurer or insurance company is preempted (and since any other state regulation of employee welfare plans is preempted under the general language of $\$ 514(a)$ ), the benefit requirements of the New Hampshire statute clearly could not be imposed on a self-insuring plan.

61. This problem is compounded by the fact that employers unable to afford the insurance requirements imposed by state law are more likely to self-insure, although they are less able to bear the financial costs of doing so. 160 PENS. REP. (BNA) A-16 (Oct. 24, 1977) (testimony of ERIC representative Robert S. Stone before Oversight Subcomm. of Sen. Comm. on Human Resources).

62. See ERISA § $3022(a)(4), 29$ U.S.C. § 1222(a)(4) (1975).

63. See, e.g., 198 PENS. REP. (BNA) A-33 (July 24, 1978); 151 PENs. RRP. (BNA) A-3 Aug. 22, 1977); 149 PENS. REP. (BNA) A-17 (Aug. 8, 1977); 134 PENS. REP. (BNA) A-17 (Apr. 25, 1977).

64. See Brummond, supra note 4, at 124; 160 Pens. Rep. (BNA) A-19 (Oct. 24, 1977), illustrating the ways in which $\$ 514$ could be altered to preserve preemption of the state laws relating to employee pension plans, while explicitly negating the possibility that state laws are superseded in the employee welfare plan area.

65. Although many states attempted to regulate employee welfare plans, only a few had enacted laws regulating pensions, and inost of these laws were not as comprehensive as ERISA. Brummond, supra note 4 , at 114 . Because state regulation of welfare plans was inore highly developed, the need for total preemption was less compelling, and the resultant disruption of the state regulatory scheme was more extensive than has been the case with pension plans.

66. See notes $5 \& 57$ and accompanying text supra. 
A more satisfactory approach would be to amend ERISA so that the Act, as a whole, no longer applies to employee welfare plans. ${ }^{67}$ By removing the partial federal regulation in this area, such an approach would eliminate the preemption confusion concerning employee welfare plans, ${ }^{68}$ while neither reintroducing the Whaland problems ${ }^{69}$ nor undercutting the thrust of Congress's efforts in the area of pension plan regulation. ${ }^{70}$ Congress could then consider enacting new, comprehensive legislation focusing exclusively on the needs of employee welfare plans. ${ }^{71}$

2. Alternative Judicial Interpretations of Section 514. Absent the statutory changes suggested above, the problems raised by the court of appeals' approach in Whaland could be reinedied by any one of several alternative constructions of section 514. If the provision were read as preempting all state laws, including insurance laws, that indirectly regulate einployee benefit plans, ${ }^{72}$ the problems of continuous litigation and lack of national uniformity would not arise. Congress could then require, through amendments to ERISA, that certain minimum benefits be provided, ${ }^{73}$ and thereby monitor the costs of enployee welfare plans, while ensuring that certam basic benefits are provided. Alternatively, Congress could ensure that costs will not be prohibitive by allowing the employer ${ }^{74}$ or employee organization establishing a plan to determine the benefits to be provided. ${ }^{75}$

67. This might be done simply by deleting all references to employee welfare plans from titles $I$ and III of the Act.

68. A strong argument can be made for this approach in light of the fact that the substance of ERISA reflects a lack of careful congressional consideration of the implications of preemption of state laws relating to employee welfare plans. See Brummond, supra note 4, at 117.

69. See notes 52-61 and accompanying text supra.

70. A review of the Congressional hearings preceding ERISA reveals that Congress was primarily concerued with remedying abuses found in the employee pension plan area, and the statute itself refiects that emphasis. Thus, titles II and IV are totally inapplicable to welfaro plans, as are parts two and three of title I. See note 4 supra. The name of the Act, the Employee-Retirement Income Security Act of 1974 is also indicative of Congress's primary concern.

71. Congress's inattention to the peculiar needs of employee welfare plans resulted in serious inadequacies in the present regulatory scheme. In addition to the failure of ERISA to provide guarantees that a welfare plan will meet its obligations, it does not specifically provide for the establishment of these plans or for sufficiently detailed reporting. ERISA also fails to provide guidance concerning the type of benefits that should be included in employee benefit plans, or who is to decide the extent of these plans. For a discussion of other madequacies, see Brummond, supra note 4, at 117-18; 184 PeNs. Rep. (BNA) A-13 (April 17, 1978) (remarks of Willie R. Barues).

72. See notes 34-36 and accompanying text supra.

73. For example, Congress might adopt part of the National Association of Insurance Commissioners (NAIC) model comprehensive health legislation, which provides that employers must provide group insurance coverage that meets certain minimum standards. Sce NAIC Model Compremensive Health Insurance and Health Care Cost Containment Act \& 5, reprinted in 2 National Association of Insurance Commissioners, Procesdings 410 (1976). This type of legislation would require considerable research, since ERISA's legislativo history suggests that Congress has not given the subject any consideration.

74. Cf. Standard Oil v. Agsalud, 442 F. Supp. 695 (N.D. Cal. 1977) (finding some evidence that Congress intended that the private sector, rather than the federal governinent, determine the benefits to be included in employee welfare plans).

75. ERISA-governed plans may be set up by an employer and an employee organization acting together. See note 3 supra. In such cases, the types of benefits provided may be mandatory subjects of bargaining in the collective bargaining context, See Nationnl Labor 
Total preemption, imcluding preemption of insurance laws indirectly regulating employee welfare plans, raises serious problems, however. States would have great difficulty regulating insurance companies at all because the same agents, policies, and funds used on employee welfare plans would be used on other insureds..$^{76}$ In addition, states would be limited in the extent to which they could initiate progressive legislation to protect employees.77 More broadly, total preemption would exempt from state regulation many activities that are only tangentially related to the employee welfare plans. For example, ERISA, if broadly construed,.would preempt laws governing community property, sex discrimination, and other areas never considered by Congress when enacting the statute. ${ }^{78}$

The greatest single problem with sweeping preemption is that it would create a vast regulatory vacuum in the area of employee welfare plans. ${ }^{79}$ In contrast to the limited provisions for fiduciary and disclosure requirements provided by ERISA, state regulation of welfare plans is comprehensive, particularly in the area of financial stability. ${ }^{80}$ Removing the states' presence in this field would force courts, absent a broad congressional initiative, to undertake the burdensome task of formulating a federal common law to fill the regulatory vacuum. 81 Furthermore, even if Congress devised a comprehensive statutory scheine, the task of supervising the numerous plans would be staggering. ${ }^{82}$

A preferable solution, implicitly suggested by the district court de-

Relations Act $\S 9(a), 29$ U.S.C. $\S 159$ (a) (1976). For a discussion of the complex interrelation of federal labor law and state-imposed employee benefit requirements, see White Motor Corp. v. Malone, 545 F.2d 599 (8th Cir. 1976), rev'd, 435 U.S. 497 (1978).

76. See Brummond, supra note 4, at 118-19 (discussing the problems of regulating "half a company").

77. See 184 Pens. Rep. (BNA) A-13 (Apr. 17, 1978) (preemption of state health insurance laws has stymied states' abilities to create new and unique health provisions).

78. See Pattiz, In a Divorce or Dissolution Who Gets the Pension Rights: Domestic Relations Law and Retirement Plans, 5 PEpPERDINe L. Rev. 191, 231 n.181 (1978); 160 Pens. REP. (BNA) A-17, 18 (Oct. 24, 1977). Cf. Time Ins. Co. v. Department of Indus., Labor \& Human Relations, No. 154-423 (Circuit Court, Dane County, Wis., filed Jan. 3, 1978) (considering the applicability of state anti-discrimination law to employee welfare plan). See also Kerbow v. Kerbow, 421 F. Supp. 1253 (N.D. Tex. 1976) (seeking to compel plan to withhold ERISA-governed pension payments awarded to spouse in divorce settlement); In re Marriage of Pardee, 408 F. Supp. 666, 669 n.4 (C.D. Cal. 1976) (imtent to regulate pension plans does not necessarily include intent to control state's distribution of assets in divorce proceedings).

79. See note 71 supra.

80. See Brummond, supra note 4, at 118. See also Car. Health \& SAFETY Code $\$ \S 1340-$ 1399.5 (West 1977) (held preempted by ERISA in Hewlett-Packard Co. v. Barnes, 571 F.2d 502 (9th Cir.), cert. denied, 99 S. Ct. 108 (1978)); HawaII Rgv. STat. \$\$ 393-1 to -51 (1976) (held preempted in Standard Oil v. Agsalud, 442 F. Supp. 695 (N.D. Cal. 1977)); IDAHO CODE $\$ \$ 41-4003(1), 41-4004(1)$ (1977).

81. See, e.g., In re C.D. Moyer Co. Trust Fund, 441 F. Supp. 1128 (E.D. Pa. 1977); Wayne Chem., Inc. v. Columbus Agency Serv. Corp., 426 F. Supp. 316 (N.D. Ind.), aff'd on other grounds, 567 F.2d 692 (7th Cir. 1977). The courts' conclusion that a federal common law should be formulated was based on legislative history indicating that the courts are to fashion a federal common law as they do for the Labor Management Relations Act. See 120 CoNo. Rec. 29,942 (1974) (remarks of Sen. Javits).

82. See Brummond, supra note 4, at 119; 191 Pens. Rep. (BNA) A-16, A-17 (June 5, 1978) (testimony of Herbert W. Anderson). Brummond points out that the number of employee welfare plans affected would be unmanageable given the size of the Department of Labor's staff. Supervision would be further hindered because it would be organized through the Department on a regional, rather than local basis. 
cision in Whaland, is to imterpret ERISA's preemption provisions as displacing state laws only in those areas that the Act specifically regulates. ${ }^{83}$ This approach, which has been used by a few other district courts, ${ }^{84}$ avoids creating the regulatory vacuum that follows broader preemption. It differs froin the court of appeals' approach in that it requires courts to determine whether Congress sought to regulate the activity before they decide whether the state insurance laws are preempted, ${ }^{85}$ rather than establishing the rule that state insurance regulation of any entity other than an employee welfare plan is allowed.

Analysis under this approach begins by asking whether the state law relates to einployee welfare plans, ${ }^{86}$ and if it does, ${ }^{87}$ if the law is one governing insurance. ${ }^{88}$ If the answer is again affirmative, the inquiry turns to whether the state law regulates an area covered by titles I or IV of ERISA. If it does not, the state law inay operate, even if it directly regulates employee welfare plans. This approach results in loss of some federal uniformity of regulation. The problem of encouraging self-insurance is avoided, however, because states can directly regulate some aspects of all employee welfare plans without the subterfuge of claiming to be regulating imsurance companies. The regulatory vacuum is also avoided, and though there may be some litigation over whether a state law regulates disclosure or fiduciary standards, the issues seein nuch inore clearcut than those raised by the court in Whaland. ${ }^{80}$

83. See note 21 and accompanying text supra. The district court noted that the legislativo history of ERISA did not address the issue of preemption of substantive insurance statutes, and that the intent of ERISA was to deal withs reporting and fuuding requirements of employee benefit plans and not with the regulation of insurance. Dawson $v$. Whaland, No. 76-266 (D.N.H. Feb. 11, 1977) (available on Lexis).

84. See, e.g., Hewlett-Packard Co. v. Barnes, 571 F.2d 502 (9th Cir.) (dictum), cert. denied, 99 S. Ct. 108 (1978); Insurers' Action Council, Inc. v. Heaton, 423 F. Supp. 921 (D. Minn. 1976). In refusing to find preemption of the Minnesota Comprehensive Insuranco Act, the Heaton court noted that ERISA imposes only reporting and disclosure duties ou welfare plans, and held that, since this has "nothing to do with the substance of the insuranco plans which einployers must offer their employees,' it is not preemptive. Id. at 926.

85. In Whaland, the court of appeals looked at the regulation of the benefit plan qua plan, and was seemingly unconcerned with the impact of state law on the plan as long as it was not directly aimed at employee welfare plans. The proposed approach provides that both direct and indirect regulation of employee welfare plans would be preempted if Cougress has legislated regarding a particular aspect of the plans. This latter approach ensures that plans are not at all affected by state regulation if Congress has legislated in the area.

86. It has been suggested that the "relating to" language should be changed to "regulate." See 160 PENS. REP. (BNA) A-19 (Oct. 24, 1977) (testimony before the Labor Subcommitteo of the Senate Human Resources Comm.). This change would have the further effect of limiting preemption of state laws by focusing squarely on those laws that regulate employee welfare plans.

87. If the state law does not relate to employee welfare plans, it does not fall within the ambit of $\S 514(\mathrm{a})$ and is not governed by ERISA.

88. If the question of whether the law is an insurance law is answered in the negative, the state law comes squarely within $\$ 514(\mathrm{a})$ and is preempted. Presumably, state laws that do not regulate insurance but do relate to employee relfare plans could include laws governing such areas as divorce, inheritance, and tort. This illustrates the need for adopting the proposal described at note 86 supra, because it eliminates the possibility of preempting state laws ouly tangentially relating to employee welfare plans.

89. For instance, it seems easier to answer the question of what is a disclosure statute than to engage in the inquiry of whether the statute really regulates insurance compamies or whether it is a veiled attempt to directly regulate employee welfare plans. See note 54 supra. 


\section{CONCLUSTON}

Section 514 of ERISA does not lend itself to easy conclusions about what Congress intended in the area of employee welfare plans. The decision of the court of appeals in Wadsworth $v$. Whaland represents a plausible interpretation of the language of the statute, but its conclusion creates serious problems for future courts and plan administrators, not only because it allows'extensive indirect state regulation of employee welfare plans, but also because it encourages plans to becoine self-insurers to avoid state regulation. A better judicial resolution would be to read ERISA to require preemption of state laws only to the extent that the Act explicitly regulates various aspects of the employee welfare plan area. This solution does not focus on whether employee welfare plans are being directly or indirectly affected, but instead considers the more important question of whether Congress actually intended to regulate a particular aspect of these plans.

Leslie C. Levin 